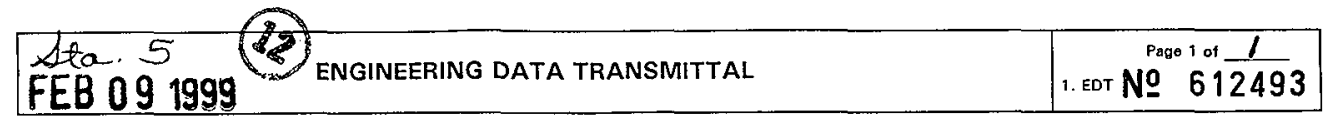

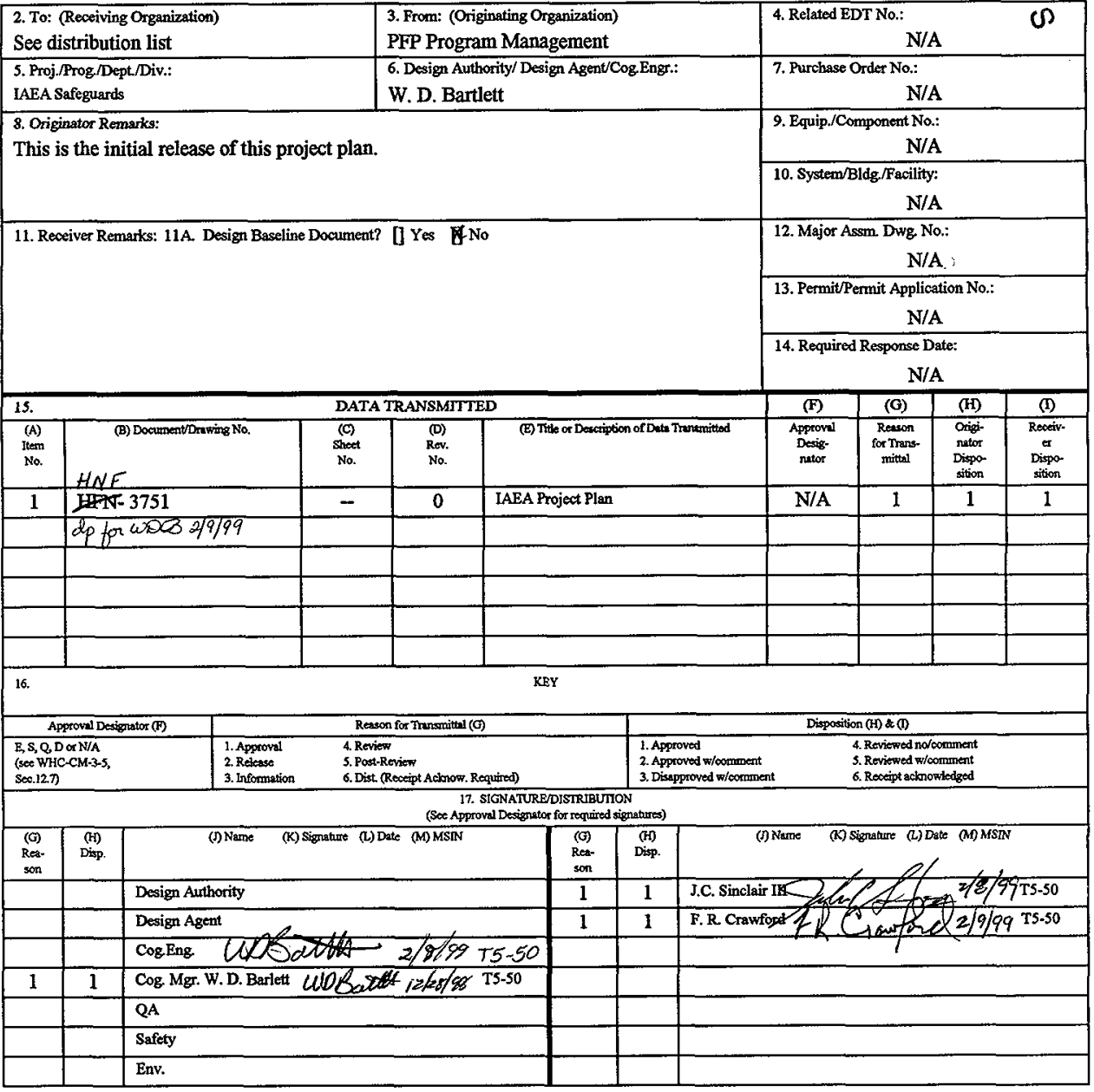

\begin{tabular}{|c|c|c|c|c|}
\hline$\underbrace{18.31-98}_{\substack{\text { Wignature of } \\
\text { Date } \\
\text { originator }}}$ & 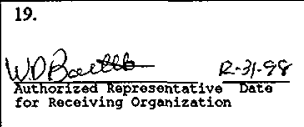 & $\begin{array}{l}20 . \\
\text { Design Authority } \\
\text { Cognizant managar }\end{array}$ & $\frac{12-31-48}{\text { Date }}$ & $\begin{array}{l}\text { 21. DOE APPROVAI (if required) } \\
\text { Ctrl. No. } \\
\text { [] Approved } \\
\text { i] Approved w/ comments } \\
\text { [] Disapproved w/ comments }\end{array}$ \\
\hline
\end{tabular}

BD-7400-172-2 (05/96\} GEF097 
HNF-3751, Rev. 0

\title{
Project Plan \\ International Atomic Energy Agency (IAEA) Safeguards Project Plutonium Finishing Plant
}

\author{
W. D. (Dean) Bartlett
}

B\&W Hanford Company, Richland, WA 99352

U.S. Department of Energy Contract DE-AC06-96RL13200

EDT/ECN: 612493

Org Code: 15000

B\&R Code: EW7040000
UC: 2050

Charge Code: 100749/AA30

Total Pages: 17 upes $2 / 84$

Key Words: Project Management Plan, IAEA, Safeguards

Abstract: Project Management Plan for continued IAEA Safeguards of materials at Hanford as well as stabilization and shipment of IAEA Safeguarded Material to their final storage destination.

TRADEMARK DISCLAIMER. Reference herein to any specific commercial product, process, or service by trade name, trademark, manufacturer, or otherwise, does not necessarily constitute or imply its endorsement, recommendation, or favoring by the United States Govemment or any agency thereof or its contractors or subcontractors.

Printed in the United States of America. To obtain copies of this document, contact: Document Control Services, P.O. Box 950, Mailstop H6-08, Richland WA 99352, Phone (509) 372-2420; Fax (509) 376-4989.

DOES NOT CONTAIN! CLASSIFIED OA

UNCLASSTFIED CONTROLLED

NUCLEAR INFORMATION
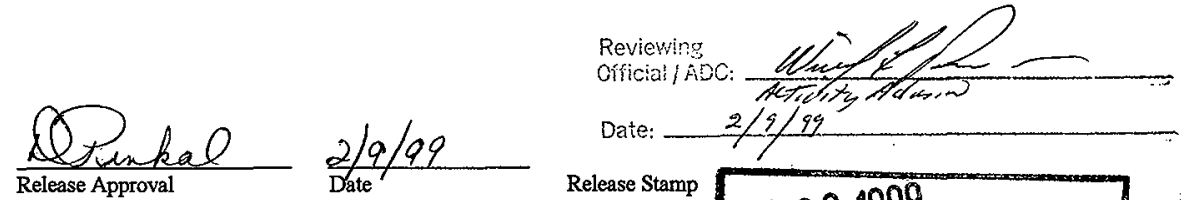

Date:

$2 / 9 / 99$

Release Stamp

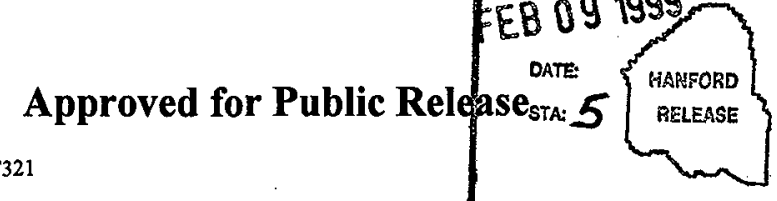




\section{TABLE OF CONTENTS}

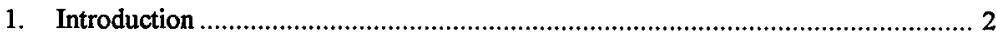

2. Work Scope

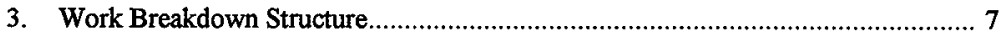

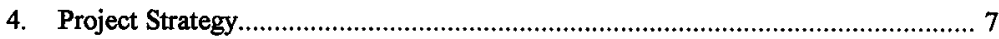

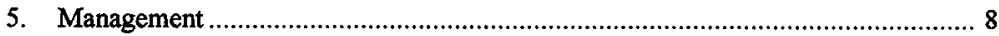

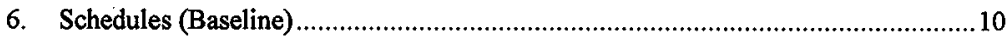

7. Cost Estimate

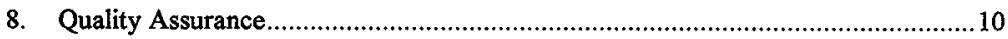

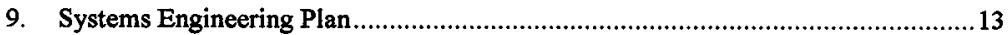

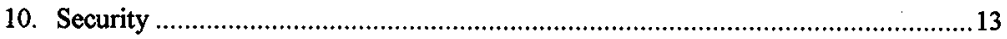

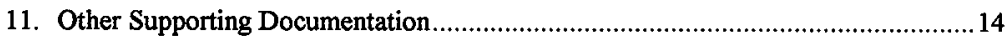

\section{LIST OF FIGURES}

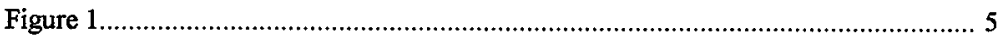

Figure 2

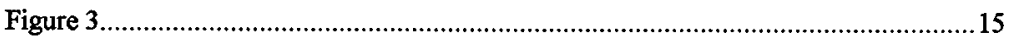




\section{Project Plan \\ International Atomic Energy Agency (IAEA) Safeguards Project \\ Plutonium Finishing Plant \\ November 16, 1998}

1. Introduction

\subsection{Project Plan Purpose}

This plan presents the overall objectives, description, justification and planning for the Plutonium Finishing Plant (PFP) International Atomic Energy Agency (IAEA) project. The intent of this plan is to describe how this project will be managed and integrated with other facility stabilization and deactivation activities. This plan supplements the overall integrated plan presented in the PFP Integrated Project Management Plan (IPMP), HNF-3617, Rev. 0.

This project plan is the top-level definitive project management document for the PFP IAEA project. It specifies the technical, schedule, requirements and the cost baselines to manage the execution of the IAEA project. Any deviations to the document must be authorized through the appropriate change control process.

\subsection{Project Description}

The IAEA Safeguards Project provides the necessary support and controls necessary required for U.S. Department of Energy (DOE) Headquarters (HQ) and IAEA for tours, verification inspections, IAEA vault corrective and preventive maintenance, and vault security maintenance.

\subsection{Project Mission}

This project is part of the PFP Stabilization and Deactivation Project. The Stabilization and Deactivation Project is discussed in the Hanford Site Integrated Stabilization Management Plan (SISMP) and the PFP IPMP. The overall project mission is provided in the IPMP.

The mission of the of the IAEA Safeguards Project is to stabilize, provide interim storage, package and ship plutonium $(\mathrm{Pu})$ bearing material placed under IAEA safeguards at the PFP. 


\subsection{Project Background}

In September of 1993 President Clinton offered to place excess United States of America (USA) nuclear materials under IAEA safeguards. In January of 1994, the Hanford Site was identified as the second site (Oak Ridge was the first) in the USA to be prepared for placement on the eligibility list for IAEA safeguards selection. Planning and preparation started at Hanford in February of 1994.

Approximately 1 metric ton of Pu oxide in various levels of concentrations, enrichments, and purity are under IAEA safeguards at the site. Approximately 1,100 items reside in 42 cubicles in a single PFP vault. The placement of an approximate metric ton was done in two separate phases. The first phase, termed the "Initial Offer," consisted of placing approximately 500 items under IAEA safeguards, and it was completed in December 1994. The second phase, called the "Inventory Change," consisted of approximately 600 items, and it was completed in August 1995. In November 1996, one additional container was placed under safeguards.

Since the initial December 1994 offer, IAEA personnel have been performing monthly ad hoc inspections. These inspections are implemented as part of a negotiated "IAEA Design Information Questionnaire package for the PFP," Revision 1.0, dated March 3, 1998. These will continue until formal inspections are implemented after a "Facility Attachment for the Hanford Site" has been negotiated between the U.S. and the IAEA. In addition, once every year, the agency verifies the inventory through random item selection and a variety of measurements.

\subsection{Project Relationship to the Total Stabilization Program}

This project is one of several identified to complete stabilization of $\mathrm{Pu}$ at PFP, safely store it onsite, ship it offsite for storage or disposal, and transition the facility to a condition suitable for long term, minimum cost surveillance and maintenance. The overall hierarchy of planning documents is as follows:

- Integrated Project Management Plan, presents the overall planning strategies and scope for the above.

- Project planning at the functional level

- Facility Surveillance and Maintenance

- Material Storage (vaults)

- IAEA support activities (THIS PLAN)

- Material Stabilization

- Project Planning to support Material Stabilization activities

- Metals and Oxides Stabilization 
- Solutions Stabilization

- Polycubes Stabilization

- Residues Disposition

- Project W-460, Plutonium Stabilization and Packaging (PuSAP) construction

- Plutonium Shipping and Handling (PuSH) Operations

- Fuels Management

- Special Nuclear Materials (SNM)

- Special Isotopes

- Facility Transition

- Material Shipments

- Post Deactivation Surveillance and Maintenance

2. Work Scope

\subsection{Work Scope}

\section{Process Flow Description}

Figure 1 provides (1) the major process steps associated with the IAEA project and (2) the overall relationships to the Defense Nuclear Facilities Safety Board (DNFSB) Recommendation 94-1 activities. Material stored in room 3 of the $2736-Z$ Building will be stabilized and packaged to 3013 criteria. Interim storage will be provided if the PuSAP facilities are not available. Final packaging to DOE-STD-3013 criteria for long term storage and shipment to the Savannah River Site (SRS) will be provided following PuSH processing activities.

\section{Facility Modifications/Equipment Installation}

No additional facility modifications or equipment installation will be required. 


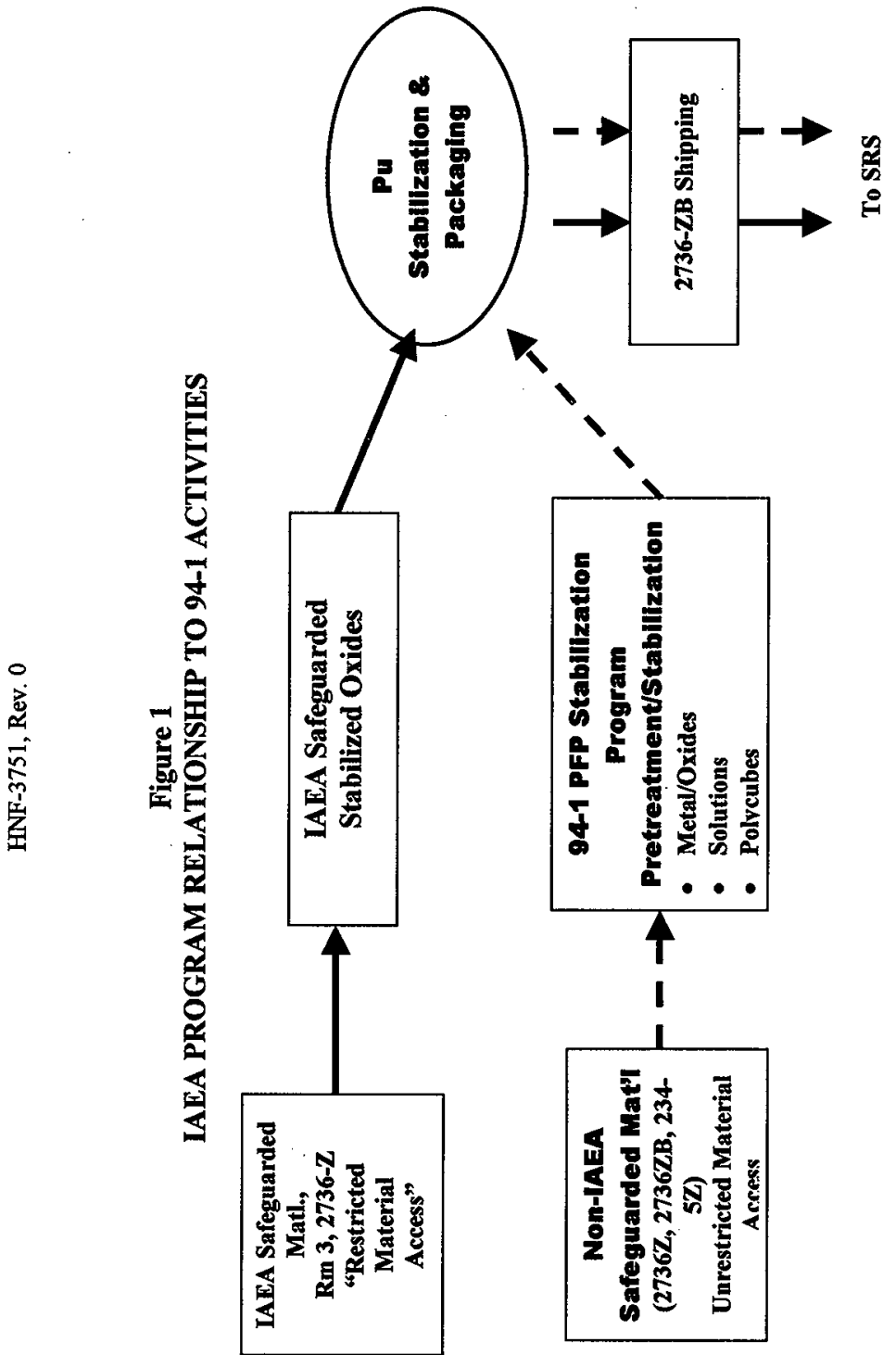




\section{Operations}

This work scope includes support to DOE-HQ and IAEA, tours and verification inspections, IAEA vault corrective and preventative maintenance and vault security maintenance.

\subsection{Requirements Baseline}

\subsubsection{Driving Requirements}

Driving requirements are those requirements that define the project mission. The DNFSB Recommendation 94-1 Hanford SISMP, Revision 5, dated May 1997 has been the source of driving requirements for the PFP projects. In the case of the IAEA work, there are no specific requirements identified in the SISMP. Requirements for this work are contained in agreements between the USA and the IAEA for the Application of Safeguards in the USA.

\section{Interpretation:}

An approach for IAEA safeguards before, during and after the stabilization process will be developed which allows the IAEA to reach a conclusion.

\section{Assumptions:}

Materials processed in batches that provide traceability from storage items to stabilized items.

Items under safeguards and those not under safeguards are not mixed.

No sensitive date will be involved.

No future, additional Hanford Plutonium is currently planned to be offered for placement under IAEA safeguards until after it has been stabilized.

Early integration of IAEA perspective into design of PuSAP and Vault modifications will eliminate significant impacts on the PuSAP design and installation.

Negotiations of IAEA oversight requirements (currently four options) will not result in significant impacts to this project. 


\subsubsection{Derived Requirements}

Derived requirements are those requirements that flow down from higher level requirements or assumptions. No derived requirements have been identified at this time.

\subsubsection{Key Interfaces}

Each of the tasks included in this project have a shipping and packaging interface which includes the PuSAP Stabilization and Packaging to DOE-STD-3013 and SRS or Los Alamos National Laboratory packaging and shipping standards. It is assumed that it will be possible to establish each of these interfaces as currently planned.

Due to the possibility of several related processes going on at the same time, this project will have interfaces with the other subprojects. These interfaces include items such as material flow, feed and stabilized material transfers, staging, radiation effects and airborne radiation area status. Evaluations of the material flow to the different DNFSB Recommendation 94-1 operations and the interactions between them will need to be conducted as required to ensure a smooth flow of material.

\subsubsection{Key Milestones}

There are no formal milestones established at this time.

3. Work Breakdown Structure

The IAEA Project Work Breakdown Structure (WBS) is shown in Section 5.3. The WBS is a product-oriented hierarchy of the work and products for the subproject and will be used to define and inter-relate the subproject work.

\section{Project Strategy}

The IAEA Safeguards Project will complete stabilization, packaging and shipment of the material placed under IAEA safeguards. The strategy for this project is to complete the work within the current project management structure, minimize impacts to the other projects' tasks and complete the IAEA work as efficiently as possible. 
HNF-3751, Rev. 0

\section{Management}

The IAEA project is under the direction of PFP Senior Director. Support for the subproject activities is provided by various support groups within the PFP organization.

\subsection{Project Management Roles and Responsibilities}

The individual cost account packages for this subproject are identified in section 5.3.

\subsubsection{Project Manager}

The project manager is responsible for the following activities within this subproject:

- Planning, managing and maintaining the technical, schedule, and cost baselines for the project.

- Selecting and directing cost account managers responsible for delivering discrete products and services defined by assigned WBS elements.

- Maintaining a trained and qualified work force to complete the cost account products.

- Effectively resolving issues impacting project completion.

- Providing monthly project status of performance to the PBS manager.

- Acting as primary point of contact for all issues pertaining to the project.

- Obtaining and directing other support functions necessary to ensure project completion.

- Providing effective personnel resources utilization.

\subsubsection{Cost Account Managers} following:

The individual cost account managers are responsible for the

- Planning and completing the applicable cost account work scope in accordance with the technical, schedule and cost baselines established in this plan.

- Identifying work package managers as needed and ensuring that their work is properly managed to achieve control account objectives.

- Performing work in a manner that meets the subproject's quality objectives. 
- Ensuring resource requirements are identified to matrix organizations.

- Maintaining a trained and qualified work force to complete the cost account products.

- Achieving operational safety and compliance with permit requirements.

- Evaluating and reporting monthly cost account status to the project manager.

- Maintaining required operational efficiencies to achieve project objectives.

- Developing and implementing corrective action plans as needed.

- Directing and working with work package managers to complete the work packages as planned.

\subsection{Primary Project Interfaces}

Primary project interfaces are shown on Figure 2.

5.3 Responsibility Assignment Matrix

\begin{tabular}{|l|l|l|}
\hline \multicolumn{1}{|c|}{ WBS } & \multicolumn{1}{|c|}{ TITLE } & \multicolumn{1}{c|}{$\begin{array}{c}\text { RESPONSIBLE } \\
\text { MANAGER }\end{array}$} \\
\hline 1K6E & $\begin{array}{l}\text { IAEA Safeguards Support at } \\
\text { PFP }\end{array}$ & W. D. (Dean) Bartlett \\
\hline 1K6EA & $\begin{array}{l}\text { IAEA Safeguards Support at } \\
\text { PFP }\end{array}$ & W. D. (Dean) Bartlett \\
\hline 1K6EA1 & PFP Support to HQ \& IAEA & W. D. (Dean) Bartlett \\
\hline 1K6EA2 & $\begin{array}{l}\text { Verification Inspections/Tours } \\
\text { at PFP }\end{array}$ & W. D. (Dean) Bartlett \\
\hline 1K6EA3 & $\begin{array}{l}\text { IAEA Vault Miscellaneous } \\
\text { Maintenance }\end{array}$ & W. D. (Dean) Bartlett \\
\hline 1K6EA4 & $\begin{array}{l}\text { Vault \# 3 Security } \\
\text { Maintenance }\end{array}$ & W. D. (Dean) Bartlett \\
\hline 1K6EA5 & $\begin{array}{l}\text { IAEA Vault Project } \\
\text { Management }\end{array}$ & W. D. (Dean) Bartlett \\
\hline
\end{tabular}

5.4 Authority/Responsibility Matrix

Authority and responsibilities for this project are summarized in Figure 2 and Section 5.3 of this project plan. 
6. Schedules (Baseline)

The IAEA project schedule is provided in Figure 3. Detailed schedules will be developed and/or updated and will be maintained in Primavera Project Planner (P3).

\section{Cost Estimate}

The funding requirements for this project are listed in the following table.

\begin{tabular}{|c|c|}
\hline FISCAL YEAR & $\begin{array}{l}\text { FUNDING REQUIREMENT } \\
(\$ K)\end{array}$ \\
\hline 1999 & 516 \\
\hline 2000 & 643 \\
\hline 2001 & 643 \\
\hline 2002 & 643 \\
\hline 2003 & 643 \\
\hline 2004 & 643 \\
\hline 2005 & 643 \\
\hline 2006 & 643 \\
\hline 2007 & 643 \\
\hline 2008 & 559 \\
\hline 2009 & 559 \\
\hline 2010 & 559 \\
\hline 2011 & 581 \\
\hline 2012 & 601 \\
\hline 2013 & 601 \\
\hline 2014 & 601 \\
\hline TOTAL & 9,721 \\
\hline
\end{tabular}

8. Quality Assurance

\section{A. Quality Assurance Document Hierarchy}

The B\&W Hanford Company (BWHC) Facility Stabilization Project Quality Assurance Program Plan (QAPP) (Reference FSP-MP-004) documents the BWHC organization and functional responsibilities and interfaces for quality assurance (QA) and identifies procedures, instructions, and management systems to implement requirements appropriate to the BWHC work scope.

BWHC is currently responsible for the Facility Stabilization Projects and Advanced Reactor Transition. Due to the varied nature of BWHC Projects, the BWHC QAPP is a combination of an umbrelia BWHC QAPP, which covers company activities and a set of Facility/Project specific QAPPs tailored to specific project tasks. 
HNF-3751, Rev. 0

The PFP QAPP, FSP-PFP-5-8, Volume 2, Section 15.1, of the PFP Administration Manual implements the QA requirements of Title 10 , Code of Federal Regulations (CFR), Part 830.120, "Quality Assurance Requirements," and the Project Hanford Quality Assurance Program Description (QAPD), HNF-MP599 and constitutes the specific PFP QAPP. 
HNF-3751, Rev. 0

Figure 2

\section{Primary Project Interfaces}

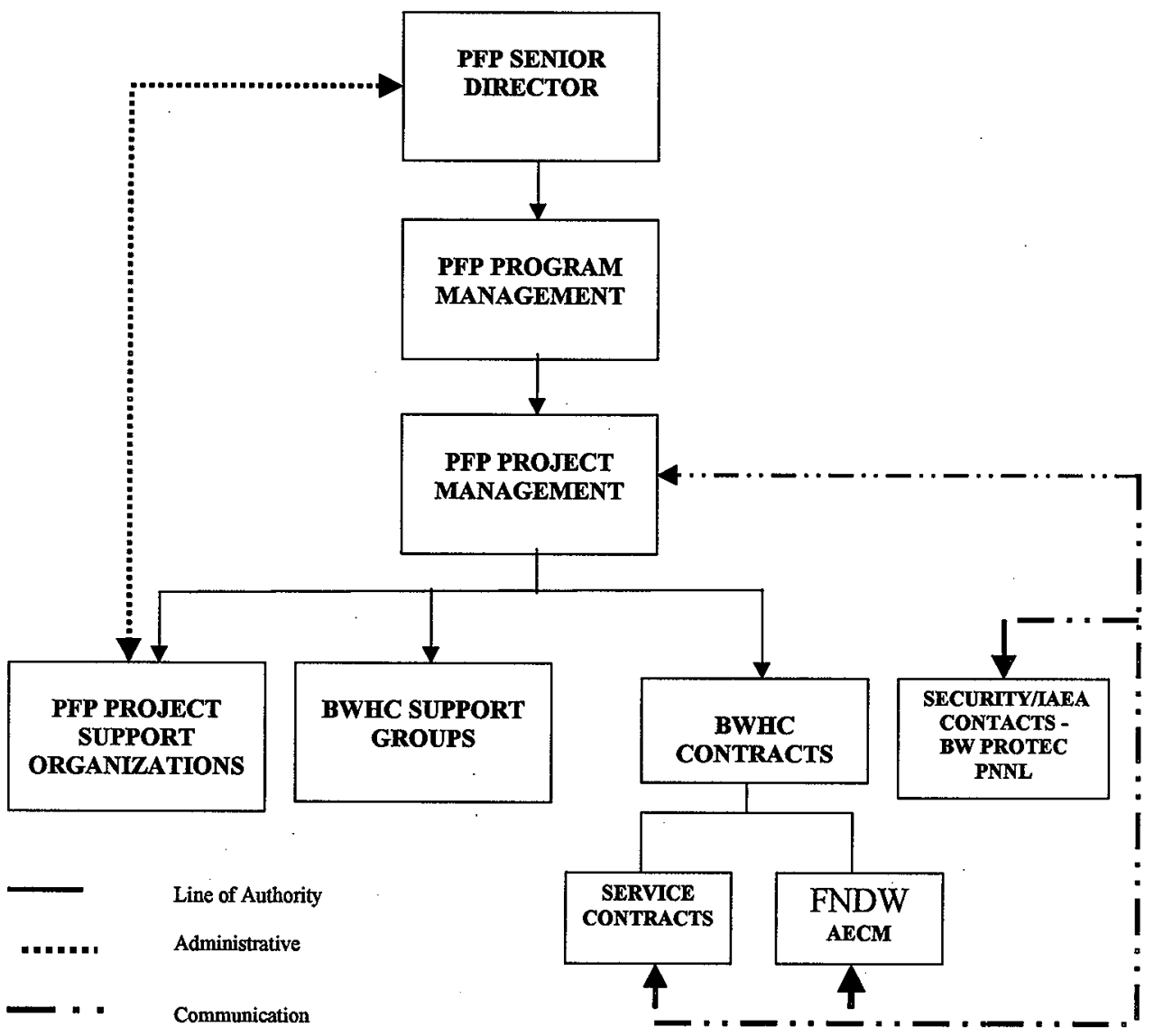




\section{B. Quality Assurance Organization and Interface}

The PFP structure, interfaces and levels of authority of the PFP organization are defined in the PFP Administration Manual, FSP-PFP-5-8, Section A, "Organizational Charts," and general responsibilities are described in Section B, "PFP Management Positions/Team leaders - Key Functions."

\section{Quality Assurance Requirements}

PFP is subject to the requirements of Title 10, CFR, Part 830.120, "Quality Assurance Requirements," and shall comply with the applicable requirements described in the Project Hanford QAPD, HNF-MP-559. Appendix A, "QAPD Requirements Applicability Matrix," of the PFP QAPP identifies QAPD requirements that apply to each PFP organization.

9. Systems Engineering Plan

Due to the nature of the IAEA tasks and the level of negotiations required for the work, evaluations of options and work tasks are coordinated between DOE, Richland Operations Office, NN-44, EM-64 and the IAEA Secretariat. Systems Engineering support will be provided at a PFP as it pertains to operations in the PFP.

10. Security

The PFP security program addresses the following security aspects: Physical protection of SNM, nuclear material accountability \& control, access control requirements, human reliability program protection, shipments and movement of SNM, and storage of SNM.

\section{A. Personnel Security (clearances)}

Authorized access to the process area will be controlled by positive identification that will require a "two person rule". The two-person rule requires that at least two knowledgeable people in the Personnel Security Assurance Program be in the area when work is in progress.

IAEA Inspectors' badging requirements for the PFP are prepared in advance of the planned itinerary. Positive identification is performed at the Protected Area as well as at the Material Access Area. 


\section{B. Nuclear Material Accountability and Control}

Domestic Safeguards Material Accountability and Control is applied to all SNM under International Safeguards utilizing tamper indicating seals. Material surveillance procedures (two person rule) are implemented utilizing personnel qualified under the personnel security assurance program in Category 1 SNM locations.

\section{Physical Security}

All material under International Safeguards will be protected under domestic security at all times. This will include utilization of locking devices for cubical storage and the use of transport wagons at all times. Material will be stored under vault protection when not attended. Escorting requirements shall be in effect at all times for agency personnel at PFP to insure that agency personnel are restricted to approved security plan routes and facility locations. Escorts will ensure that agency personnel are not afforded access to classified information or other domestic SNM holdings.

11. Other Supporting Documentation

Other supporting documentation and plans will be prepared to support this subproject.
A. Regulatory Compliance plan
B. ALARA Plan
C. Characterization Plan
D. Readiness Assessment Plan
E. Design Information Questionnaire
F. Windows Calorimeter Control Program
G. Health and Safety Plan
H. IAEA Security Plan 
HNF-3751, Rev. 0

Figure 3

IAEA STABILIZATION PROJECT SCHEDULE

To be Developed at a hater Date

$\frac{74}{15} \cos _{2 / 89}$ 


\section{DISTRIBUTION SHEET}

To

Distribution

Project Title/Work Order

IAEA Safeguards Project Plan

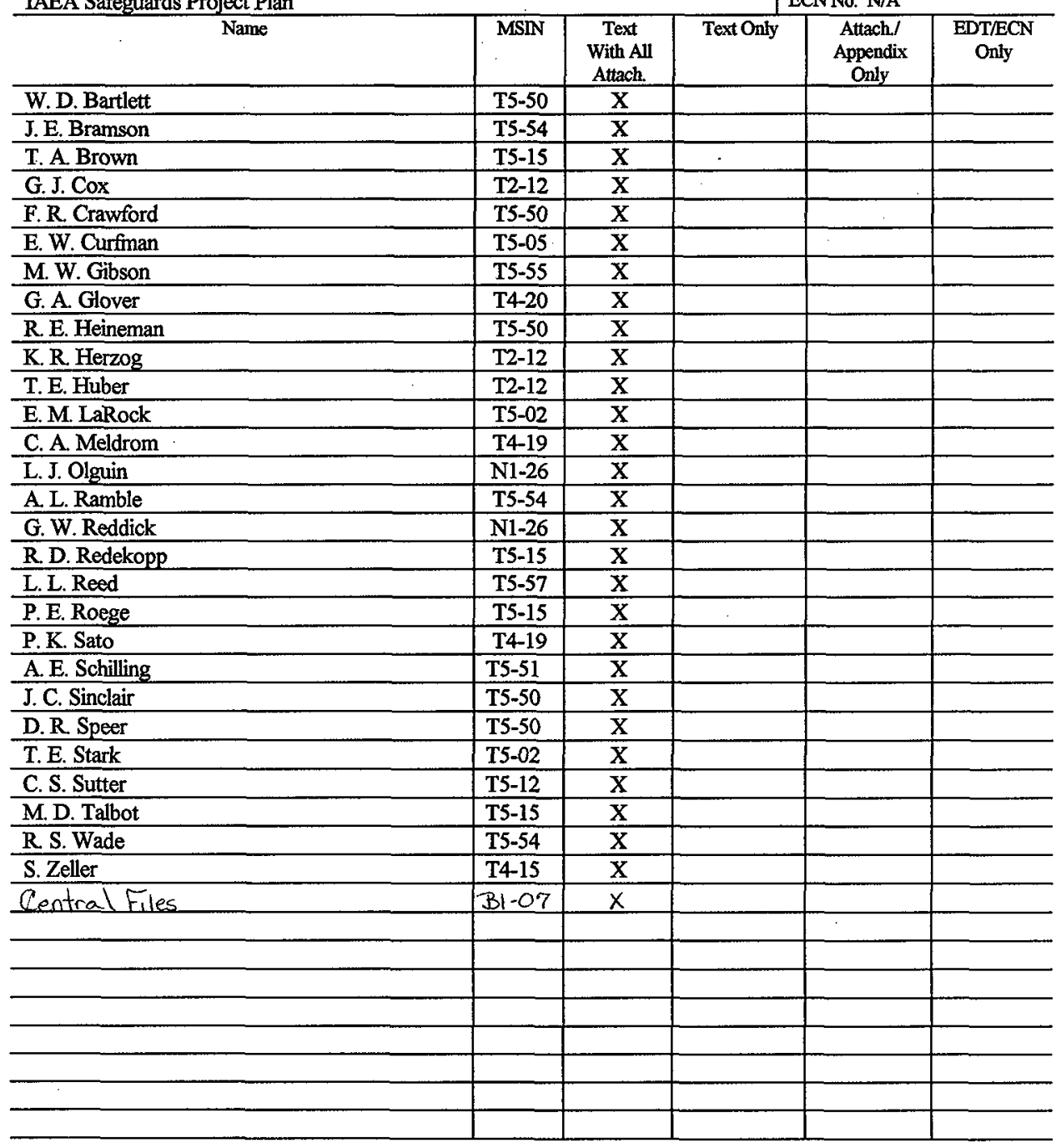

Page 1 of 1

Date December 28, 1998

EDT No. 612493

ECNNo. N/A
PFP Program Management 